\title{
Det imaginære rum
}

\author{
Af Ib Poulsen
}

Radioens rum er imaginare, altså noget lytteren forestiller sig ud fra det horte. Artiklen har tre sporgsmål som omdrejningspunkt: Hvordan etableres rum i radioen, hvad er det sarlige ved disse radiofonisk formidlede rum, og hvordan kan man begribe radioens rum teoretisk? Undervejs inddrages en rakke eksempler fra radiomontager - en genre der om nogen har udforsket mulighederne for at skabe radiofoniske rum. Artiklen skitserer afslutningsvist hvorledes man kan forankre beskrivelser af radioens rum teoretisk ved hjalp af Peirces tegnbegreb med de tre aspekter: indeks, ikon og symbol.

\section{Auditiv perception}

På flere punkter er der strukturelle ligheder mellem visuel og auditiv perception: I begge tilfælde er perceptionen retningsbestemt, og begge perceptionsformer har afstand som en central dimension. Men en total parallelisering overser det faktum at synet er bundet til en synsvinkel hvor noget er omfattet og noget er udelukket. Lyd er derimod noget der omgiver én uden skarpe grænser for hvad der er med og ikke med. Hørelsens retningsbestemthed indebærer ganske vist at man bedre hører det der foregår foran en, end det der sker bagved en, men til forskel fra synet er det man ikke kan se også med i den auditive perception. Med ørerne har man 'øjne' i nakken, ja, man har faktisk 'argus-øjne', dvs. øjne der kan se hele horisonten rundt. I og med at lyd således er noget man er i, danner kroppen i mere grundlæggende forstand end ved visuel perception udgangspunkt for den auditive perception (Theil, 1999: 91ff). Nogle lydforskere opererer på denne baggrund med tre lydzoner: nærzone, mellemzone og fjernzone (Leeuwen, 1999; Schafer, 1977), mens andre bruger andre betegnelser, f.eks. den umiddelbare zone, støttezonen og baggrundszonen hvor støttezonen består af nabolyde til lydene i den umiddelbare zone, og baggrundslyden er den der sætter scenen mere generelt (Schafer, 1977). Pointen er dog uanset betegnelser at lyden i nærzonen er den man lytter til, mens lydene i mellem- og fjernzone blot er nogle man hører. Men sker der et pludseligt skift i lyden i såvel mellemgrund som baggrund kan det indebære at fokus flyttes derhen, og så er det her man begynder at lytte. Det vil sige at ændringer $i$ lydmønstret indebærer at der sker et skifte i hvad der er nærzone, mellemgrund og baggrund. Men også at det man som lyttende ønsker at fokusere på, kan blive forgrund, selvom det ikke nødvendigvis er det der er nærmest. Dynamikken mellem forgrund, mellemgrund og baggrund er således noget der både genereres af omverdenen og af den lyttende (se også Kahn \& Whitehead, 1992 samt Truax, 2001).

\section{Radioens rum}

Når man lytter til radio, er udgangspunktet den erfaring man medbringer om den akustiske perception fra hverdagen. Det særlige ved de auditivt formidlede rum man hører i radioen, er at de er imaginære. Ikke sådan at forstå at alle radioudsendelser sendes fra imaginære rum, men således at lytteren på baggrund af de lyde eller den kombination af lyde der høres, skaber sig en forestilling om et rum. Det sker mest umiddelbart når en række lyde eller klange direkte synes at angive hvilket rum der måtte være tale om. Et eksempel fra en radiomontage kan belyse denne pointe. I Nattevegteren af Stephen Schwartz fra 1971 følger man en vægter på hans natlige tur gennem Anatomisk Institut, og etableringen af rummet sker først og fremmest gennem den lyd hans skridt afgiver. Et rungende ekko angiver et stort rum med en hård gulvbelægning og nøgne vægge der kan kaste lyden tilbage, og i kraft af den meget distinkte og kraftige lyd af skridtene føler man sig som lytter placeret tæt på vægteren. I dette store, mørke, men imaginære rum skabes bevægelsen også ved hjælp af lyden alene. Skridtenes lyd med den samme tætte mikrofonafstand angiver at man som lytter følger vægteren på hans runde. Men ikke hele vejen. Ind imellem bliver man på raffineret vis placeret det sted som vægteren nærmer sig, for eksempel i forbindelse med et sted hvor der sidder en kontrolnøgle. Mens vægteren fortæller 
om sit barn og sin kone der begge har været syge, stiger skridtenes lyd i styrke indtil kontrolnøglen udpeges og skridtene standser. Ved hjælp af den stigende lydstyrke opleves det som om den gående nærmer sig det sted hvor man selv er placeret, samtidigt med at denne brug af lyden gør et bestemt sted særligt fokuseret. Hvad der altså her bliver skabt gennem den akustiske iscenesettelse - en slags koreografi for personernes bevægelser i rummet - er dels rummets karakter (stort med nøgne flader), dels lytterens imaginære placering i dette rum i forhold til vægteren, enten det er så tæt på at man nærmest er ham i kraft af den nære afstand til skridtene, eller det er fjernere fra, nemlig på et sted som vægteren nærmer sig. Lyden bliver således brugt til at skabe forestillingen om et rum af en bestemt karakter og til at skabe forestillingen om nogle positioner i rummet og nogle bevægelser i det. Som sådan indeholder montagen en række karakteristiske eksempler på hvad der også er blevet kaldt 'scenografisk montage', dvs. en montageform der består af en række forskellige lag af lyd med den hensigt at skabe en oplevelse af et rum, enten af fysik eller af psykisk karakter (Bruun \& Frandsen, 1991). Forskellen mellem begrebet om scenografisk montage og akustisk iscenesættelse er at den akustiske iscenesættelse også fokuserer på personernes bevægelser både i det ydre fysiske rum og i det mentale.

Men én ting er store og lydligt klart profilerede rum som i Nattevagteren. Hvad stiller man op med små og tætte rum uden store nøgne flader med stærk efterklang? Per Brethvads montage Oh, kom dog hjem fra 1979 drejer sig om en mindre brevdueforening nord for København, og i den giver den akustiske iscenesættelse stort set hele vejen igennem en fornemmelse af små rum - og nærhed. Det gælder inde i dueslaget hvor duernes kurren hele tiden lyder tydeligt i baggrunden, og det gælder når dueejerne lavmælt står og taler sammen. Men det forhindrer ikke at der samtidigt skabes dybde i rummet, og mange steder etablerer montagen både forgrund, mellemgrund og baggrund. Et eksempel: På et tidspunkt står en af dueejerne og fortæller om sine duer til Brethvad helt tæt på, signaleret ved lav stemmeføring, men ind imellem hæver han stemmen og signalerer dermed at han også henvender sig til de omkringstående kolleger - udvider så at sige rummet med sin ændrede stemmestyrke. I baggrunden hører man som sagt duernes kurren, en lyd der er med til at angive rummets begrænsede udstrækning i kraft af den distinkthed duernes kurren har, og ikke mindst fordi den slags lyd er kendetegnet ved i det hele taget ikke at kunne høres på større afstand. Et centralt moment i montagen er en konkurrenceflyvning hvor duerne slippes løs i nærheden af Jönköping, og hen imod slutningen hvor spændingen stiger om hvilke duer der vinder flyvningen, dvs. hvilke duer der forst vender hjem til dueslaget, sker der en åbning af rummet mod omverdenen, in casu til nogle af de andre brevdueforeninger i omegnen af København. Det sker ved at man over telefonen fortæller hinanden om hvilke tider man hver for sig har fået. Disse telefonsamtaler angiver på den ene side at den lille brevdueforening udgør en del af en større helhed, men på den anden side fastholder den lydlige iscenesættelse at det er den lille forening der er centrum. Det er fra de små rum i klubhuset der bliver ringet op til de andre, det er her der bliver ringet til, og det er ikke mindst herfra der bliver talt. Montagen er et eksempel på hvordan et lille sluttet miljø beskrives i sin kontekst i ord og navnlig ved hjælp af lyd, et miljø hvis særlige lyd - duernes kurren - hele vejen danner baggrund og omslutter det der i øvrigt foregår. Men det er på samme tid en montage der i kraft i sin særlige akustiske iscenesættelse inkluderer forskellige rum og dynamikken mellem dem til forskel fra det forholdsvis statiske og ensartede rum i Nattevegteren.

\section{Narrativ fremdrift}

I radiomontagen bruges den akustiske iscenesættelse imidlertid ikke blot til at konstruere et imaginært rum - stort eller lille. Den lydlige dimension kan også medvirke til at skabe en narrativ fremdrift i forbindelse med et forløb over tid (se også Bruun \& Frandsen, 1991 om den elliptiske montage inden for den såkaldte temporale montageform). Et tidligt og forholdsvist simpelt konstrueret eksempel herpå findes i en radiofeature fra 1956, Selskabsrejsen, produceret af Viggo Clausen. Forløbet udgør starten på turen og falder i tre afsnit. I første afsnit hører man de forskellige pårørende tage afsked med rejsedeltagerne. I det andet byder rejselederen velkommen til turen, og i det tredje orienterer han om hvad der sker den første dag på turen. Disse tre afsnit udgør samtidigt et sammenhængende forløb, og fremdriften i dette forløb skabes primært gennem lyd. I det første hører man som sagt de pårørende tage afsked, og det sker uden for bussen der skal bringe rejsedeltagerne frem til Harzen der 
er rejsens mål. Man hører en mængde stemmer på samme tid og indimellem brudstykker af dialoger og sætninger. Efter et stykke tid fades der ned for dette lydbillede, og stemmerne høres kun ganske svagt i baggrunden for snart efter helt at forsvinde. Herefter begynder rejselederen sin velkomst: Ændringen i den akustiske iscenesættelse har så at sige bragt os ind i bussen. Dernæst høres en accelererende motorlyd af en større dieselmotor, og denne lyd fortsætter lettere nedfadet under rejselederens beskrivelse af dagens forløb. Men hans stemmeklang har ændret sig. Hvor den før var naturlig, høres den nu gennem en højttaler. Igen har den lydlige iscenesættelse ført fortællingen fremad: $\mathrm{Vi}$ er ikke blot inde i bussen, nu er turen begyndt, og rejselederen har indtaget sin plads foran i bussen med mikrofonen i hånden. Denne scene på scene-teknik havde længe været kendt inden for film, men her i 1956 var den først i sin vorden på radio. En væsentlig forklaring er at det er først på dette tidspunkt at man for alvor havde fået teknisk mulighed for at bruge optagelser på lydbånd så der kunne klippes og redigeres langt mere præcist og nuanceret end man havde kunnet med de tidligere pladeoptagelser. Dertil kom ikke mindst at det var første gang man gjorde brug af en transportabel båndoptager der gav mulighed for optagelser på steder der hidtil havde været utilgængelige. Eksemplet fra Selskabsrejsen viser i al sin enkelhed hvorledes den akustiske repræsentation af de enkelte rum og navnlig overgangene mellem dem giver en mulighed for at etablere en narrativ fremdrift, noget der først og fremmest er skabt i redigeringsrummet efter at optagelserne er kommet i hus.

\section{Rum i flere dimensioner}

Et senere og mere raffineret eksempel på etableringen af imaginære rum $\mathrm{i}$ et narrativt forløb finder man i Notater fra en losseplads, produceret af Stephen Schwartz i 1987. Montagen handler om børn i USA der forsvinder, og det bliver oplyst at åbningsscenen er fra en losseplads nær ved en lille by nord for Detroit i staten Michigan hvor politiet graver efter liget af en 13 år gammel dreng der er blevet bortført året før. Den akustiske iscenesættelse af denne åbningsscene består af flere lag der lægges ovenpå hinanden efterhånden. Det første man hører er dyster ensformigt vibrerende elektronisk musik. Næste lag er mågeskrig, derpå lyden af kørende gravemaskiner, et propeldrevet fly der passerer, efterfulgt af lyden af hvordan der graves i affaldsbunkerne og til sidst en summen af et insekt, samtidigt med at speaken fortæller om fundet af en pose med påtrykte portrætter af fire forsvundne børn. Lydene afløser ikke hinanden, men bortset fra lyden af flyvemaskinen er de til stede samtidigt. De har ikke samme styrke i forhold til hinanden hele tiden, men varierer således at de senest tilkomne lyde efterhånden bliver de dominerende.

Denne komplekse akustiske iscenesættelse varetager tilsvarende flere forskellige funktioner i forhold til den historie der fortælles i montagen. For det første bidrager den til at anslå den dystre stemning der er forbundet med temaet (misbrug af børn og deres forsvinden). For det andet angiver den stedets særlige karakter (mågeskrig, lyden af store kørende maskiner der graver i affald). For det tredje at man som lytter er positioneret på selve lossepladsen og ikke i luften over den (flyvemaskinen der passerer hen over). For det fjerde at forløbet i den akustiske iscenesættelse angiver en gradvis fokusering der begynder med at lossepladsen 'ses' i fugleperspektiv, derefter fra jorden, i nærheden af affaldsbunkerne og til sidst tæt på en enkelt ting (posen) angivet ved det summende insekt hvor man som lytter samtidigt bliver positioneret helt tæt på. Den akustiske iscenesættelse minder her om et kamera der zoomer tættere og tættere ind på det der er montagens tematiske ærinde. Og endelig for det femte fungerer den akustiske iscenesættelse genrefastlæggende som en - vel at mærke - uafklaret placering mellem fiktion og fakta. I forhold til Selskabsrejsen er der således tale om en betydeligt mere sammensat og kompleks akustisk iscenesættelse.

\section{Ydre og indre rum}

Med montagen Det indre blik fra 1981 gjorde Stephen Schwartz et forsøg på at sætte lyd på en persons egen auditive perception. Rent optageteknisk er dette gennemført ved at benytte den såkaldte Kunstkopf-metode hvor der er placeret mikrofoner i øregangene på den portrætterede person. Oprindeligt var denne metode et forsøg på eksperimentelt at tilnærme sig den naturlige perception af lyd. I korthed går teknikken ud på at man skaber et kunstigt hoved med øregange og ører, heraf navnet Kunstkopf. I øregangene placeres mikrofoner, og via optagelser herigennem opnås en tilnærmelsesvis gengivelse af hvordan et menneske hører lyd. Teknikken blev første gang 
demonstreret i 1933, men blev først for alvor brugt i slutningen af 1960'erne i forbindelse med vesttysk producerede dokumentarprogrammer (se Truax, 2001; desuden Gerzon, 1975 og Stevens \& Warshofsky, 1965). Denne særlige optageteknik indebærer at personens egen tale og egne lyde er tydelig, klar og altid tættest på, mens hørbarheden af andres tale afhænger af afstand til den portrætterede og styrken i deres tale. Optagelsen er desuden foretaget i stereo hvorved afstandsdimensionen (nær/fjern) bliver suppleret med en horisontal dimension (venstre/højre) i den auditive perception. Kunstkopf-teknikken sætter med andre ord personen i centrum af montagens imaginære auditive univers, samtidigt med at teknikken illuderer oplevelsen af hvordan en person perciperer auditivt.

I Det indre blik er den radiofoniske udfordring imidlertid skærpet ved at den person der portrætteres, har været udsat for en hjerneskade der på det nærmeste helt har frataget ham evnen til at bruge sproget. Hans evne til at forstå tale er tilsyneladende ikke skadet i samme grad - det er i hvert fald hvad Kunstkopf-teknikken giver oplevelsen af - og hans evne til at opleve musik og selv at spille er velbevaret. Således er montagen ikke blot et forsøg på at konstruere et billede på en persons auditive univers, men en ganske særlig persons auditive univers hvor musik synes at være en vigtigere eller i det mindste lige så vigtig en udtryksform som sproget. Og personens vedvarende og stædige kamp for at genvinde evnen til at udtrykke sig sprogligt giver sammen med de musikoplevelser der kommer til udtryk, tillige et fascinerende - omend ikke nødvendigvis et fuldstændigt realistisk - indblik i en indre verden eller et mentalt rum hvor et af de mest selvfølgelige udtryksmidler for andre mennesker (sproget) knapt er til stede og slet ikke er selvfølgeligt. Og her udgør netop Kunstkopf-teknikken en særlig adgang til at give udtryk for dette mentale univers fordi teknikken tillader at man kommer meget tæt på. Som lytter hører man kampen hos den portrætterede for at tilegne sig et nyt ord, man hører kampen for at prøve at bruge det igen, de udtalemæssige tilløb og sukkene over de mange mislykkede forsøg. Derudover kan montagen ses som et studie i Kunstkopf-metodens særlige auditive æstetik hvor man forsøger at sætte lyd på hvordan lyd opleves.

Kunstkopf-metoden er én måde at skabe et imaginært rum der også inkluderer et indre mentalt rum. Men bestræbelsen på auditivt at skildre et imaginært mentalt rum sker også på anden måde. Et karakteristisk eksempel herpå findes i Ole Bornedals montage Knust kvern og kvestet fra 1985. Kort fortalt drejer montagen sig om oplevelsen ved at køre på motorcykel og fascinationen ved at køre stærkt, men også om at køre galt og om de omkostninger det har. Montagen har en kompliceret opbygning der implicerer flere planer. Der er et fremadskridende dramaturgisk opbygget forløb centreret om Claus der er kørt galt to gange, begge gange med alvorlige kvæstelser til følge. Undervejs optræder endnu en person, Kim, der som Claus' alter ego fortæller om den fascinerende oplevelse det er at køre på motorcykel, og om hvordan adrenalinen pumper rundt $\mathrm{i}$ kroppen når man flirter med faren ved at køre rigtig stærkt. Gensidigt kommenterer de tos udsagn hinanden, og der opstår hen igennem montagen en spænding mellem de to versioner der efterhånden undergraver troværdigheden i Kims, i takt med at Claus' tragedie rulles op. Lydligt kommer dette til udtryk gennem en stadig større kontrast mellem den akustiske iscenesættelse af de to ulykker og følgevirkningerne for Claus på den ene side, og på den anden en helt upåvirket og fortsat ubekymret stemmeføring hos Kim. Endelig er der flere steder lagt en nærmest cyklisk fortælleform ind hvor den samme episode fortælles igen og igen hvorved fortællingens episke karakter suppleres med en poetisk dimension der flytter fokus fra det fortalte til selve fortællingens form og fortælleren selv.

I montagen kombineres således flere fortællemæssige greb: Dels findes der en fremadskridende, temporalt forankret fremstilling med de to ulykker og følgevirkningerne heraf, dels en scenografisk og en refleksiv fremstillingsform (se Bruun \& Frandsen, 1991). Den scenografiske kommer især til udtryk i selve ulykkerne og på hospitalet hvor Claus befinder sig bagefter. Og begge steder indebærer den radiofoniske iscenesættelse at grænsen mellem den ydre verden og den indre overskrides. Gentagelserne af Claus' beskrivelse medfører at fokus bliver sat på ham, og når fremstillingen derudover kombineres med ekko og akustisk markering af afstand der langsomt mindskes, indebærer denne særlige auditive kodning at man tolker udtrykket som noget der foregår inde i Claus' hoved. I forhold til Det indre blik er der altså i højere grad tale om en symbolsk kodning af det auditive udtryk (ekko og lyd der synes at nærme sig) I Det indre blik mimes forankringen rent akustisk, mens det i Knust 
kvarn og kvastet sker gennem en kombination af akustik og yderligere kodninger. Endelig indebærer det refleksive lag i Knust kvern og kvastet at montagen făr en didaktisk dimension: I og med at Kims version efterhånden mere og mere undermineres af Claus' beretning, understreges faren ved at køre hurtigt på motorcykel tilsvarende.

\section{Stemme og rum}

En af de allervigtigste udtryksformer i auditive medier er den menneskelige stemme. Men inden for en række af de videnskaber der beskæftiger sig med stemmen, herunder retorikken (se f.eks. Fafner, 1977), har der været en tendens til alene at fokusere på stemmen som bærer af sproglig betydning, eventuelt koblet sammen med en æstetisk vurdering af den, men derimod ikke at behandle den som et udtryksmiddel i sig selv. Stemmen har imidlertid både et verbalt og et vokalt aspekt. Det verbale relaterer sig til dens evne til at formidle sproglig betydning, mens der ved det vokale skal forstås stemmens egne udtryksmæssige kvaliteter. Og netop i et auditivt medie spiller dette vokale aspekt en særlig rolle da personen alene er repræsenteret af den. En stor del af det vokale aspekt peger tilbage på den person der er bærer af stemmen, bl.a. køn og alder, men en del peger også hen mod den relation der forsøges skabt mellem den talende og lytteren.

Som allerede antydet i forbindelse med montagen $O h$, kom dog hjem påvirkes lytterens forestilling om rummet og personernes placering i det af stemmeføringen. Helt enkelt vil det være sådan at hvis stemmestyrken er stor, men uden at lyde kraftig, opleves rummet som stort og stemmen som placeret langt væk, og omvendt opleves rummet og i hvert fald afstanden som mindre og måske ligefrem intim hvis stemmen der taler til en gennem højttaleren, er tæt på, lav og næsten hviskende, ganske simpelt fordi denne brug af stemmen i begge tilfælde mimer den man som lytter kender fra dagligdagen.

Men stemmen bruges ikke kun til at skabe større eller mindre afstand i (imaginær) fysisk forstand. Også afstand i andre henseender kan markeres med stemmen. Således kan man opregne en række stadier fra en imaginær intim relation til imaginær offentlig relation der kan etableres alene ved variationer i lydstyrke, toneleje og grader af spændthed (Leeuwen, 1999: 27; se også Poulsen, 2001 samt Poulsen, 2006). Stemmens mulighed i radio og an- dre auditive medier er således i kraft af sine vokale kvaliteter at skabe imaginære rum både i fysisk, social og emotionel forstand. Radioens udsendelser gennem tiden indeholder et utal af eksempler. I et historisk perspektiv kan man se en tendens til at det imaginære rum er blevet mindre og at den imaginære relation er blevet mere intim. Det bliver ganske tydeligt når man sammenligner f.eks. en af Willy Reunerts radiofeatures fra slutningen af 1940'erne med en af Christian Stentofts montager fra 1980'erne, når man sammenligner en nyhedsudsendelse fra midten af 1950 'erne med en tilsvarende i dag, og når man sammenligner måden hvorpå studieværter afvikler programmerne nu i forhold til tidligere.

\section{En semiotisk sammenfatning}

Efter at have præsenteret en række måder hvorpå imaginære rum kan skabes auditivt, kunne der være anledning til at stille spørgsmålet: Hvad kendetegner disse forskellige måder, og er der på et teoretisk plan noget der er fælles for dem? Man må forestille sig at der under lytningen foretages en tolkende tilbagekobling til det rum imaginationen har skabt. Under denne tilbagekobling bliver det akustiske udtryk i form af en lydlig sansning omformet til et meningsfuldt tegn eller et kompleks af tegn under en mere eller mindre udtalt hypotesedannelse, afhængigt af hvor entydig lyden eller klangen kan fastlægges i forhold til den givne kontekst. I de allerfleste tilfælde sker det uden videre fordi det akustiske udtryk umiddelbart lader sig dechifrere, enten i kraft af lydens bekendthed eller på grund af konteksten. Men ikke altid. I den føromtalte radiomontage Knust kvern og kvestet hører man i begyndelsen kun en uregelmæssigt tikkende lyd. Kun de færreste vil umiddelbart kunne identificere den. Først når man hører en stemme fortælle om at han efter at være kørt galt med sin motorcykel ligger inde i en lille plantage med motorcyklen over sig, forstår man at lyden stammer fra den varme cylinder der langsomt afkøles. Men inden da kan man have haft mange hypoteser om hvad denne lyd måtte betyde. Her er der tale om at lydkilden er et objekt og ikke et rum, men under alle omstændigheder gælder det at lyden - eller snarere lydkomplekset - indgår i en metonymisk relation til et rum, dvs. at lyden gengiver en mere eller mindre omfattende del af rummet, dets individer og genstande.

Med afsæt i den amerikanske semiotiker 
Charles Sanders Peirce kan denne relation siges at have et indeksikalsk, et ikonisk og et symbolsk aspekt (Hartshorne \& Weiss, 1965: 143ff.). Ved det indeksikalske aspekt forstås at relationen mellem tegnet og referenten er baseret på nærhed eller kausalitet; ved det ikoniske aspekt at relationen er baseret på lighed, mens det symbolske aspekt er kendetegnet ved en konventionel eller arbitrær relation. Det enkelte tegn indeholder alle tre aspekter, men et af dem er normalt dominerende. Uanset om relationen er indeksikalsk, ikonisk eller symbolsk domineret, er det særlige ved lyd hørt i radio altså at lytteren tilskriver lyden betydning i kraft af sin tolkning af det imaginære rum - eller den imaginære genstand - som lyden formodes at relatere sig til. Med udgangspunkt i Peirce's tegnbegreb kan man sige at i radioen er lytterens oplevelse af lyden semiotiseret på karakteristiske måder: Lyd er tegn der indeksikalsk, men også ikonisk og/eller symbolsk er med til at etablere det imaginære rum. I dette lys er det således ikke kun de verbalsproglige udtryksformer i radioen der kan forstås som semiotiserede, men også de akustiske. Hvor de verbalsproglige lyde primært er semiotiserede på det symbolske plan, er de akustiske det på et indeksikalsk og navnlig på et ikonisk plan.

Lad os her til sidst kort vende tilbage til nogle af de omtalte eksempler for blot at antyde hvordan Peirce's tegnbegreb kan anvendes i beskrivelsen af den akustiske iscenesættelse.

I Nattevagteren er det umiddelbart den indeksikalske relation der dominerer: Skridtene høres som de har lydt, men i lytterens oplevelse er det snarere den ikoniske relation der er den centrale. Man oplever ikke blot skridtene som de har lydt, men skridt der mimer en vægters tur rundt $i$ en bygning præget af store rum med hårdt gulv og nøgne flader, og efterhånden som montagen skrider frem, udvides relationen til også at omfatte det symbolske aspekt så lyden af skridtene bliver udtryk for mere end blot en tur igennem Anatomisk Institut, men også en tur igennem et indre mentalt rum hos den fortællende. En tilsvarende udvidelse af relationen kan iagttages i Oh, kom dog hjem hvor duernes kurren kommer til at stå som et symbol for det lille og nære brevduemiljø i sin helhed. Videre kan man se hvorledes den ikoniske relation er bærende i Det indre blik hvor Kunstkopf-teknikken netop forsøger at mime hvorledes man oplever lyd indefra. Og endelig kan den komplekse akustiske iscenesættelse i Notater fra en losseplads beskrives som en glidning imellem en indeksikalsk og en ikonisk domineret relation, ikke mindst på grund af den genremæssige tvetydighed: Stammer lydene fra en losseplads, eller skal de blot mime en losseplads som led i en mere eller mindre fiktiv fortælling? Peirces begreber om tegnets mulige relationer til sin referent synes at give mulighed for at videreudvikle beskrivelsen af de udtryksmæssige præmisser for de imaginære rum som i radioen bliver skabt af lytteren.

\section{Litteratur}

Bruun, Hanne \& Kirsten Frandsen. (1991). "Radioæstetik og analysemetode". MedieKultur nr. 15, 67-82.

Gerzon, M. (1975, May). "Dummy head recording". Studio Sound, 42-44.

Fafner, Jørgen. (1977). Retorik. Klassisk og moderne. København: Akademisk Forlag.

Hartshorne, Charles \& Paul Weiss. (Eds.). (1965). Collected Papers of Charles Sanders Pierce, Vol. II. Cambridge, Mass.: The Belknap Press of Harvard University Press.

Kahn, Douglas \& Gregory Whitehead. (Eds.). (1992). Wireless Imagination. Sound, Radio, and the Avant-Garde. Cambridge, Mass.: The MIT Press.

Leeuwen, Theo van. (1999). Speech, Music, Sound. London: Macmillan Press.

Plantinga, Carl R. (1997). Rhetoric and Representation in Nonfiction Film. Cambridge: Cambridge University Press.

Poulsen, Ib. (2001). "Stemmen som udtryksmiddel i radioen". In Pia Jarvad m.fl. (red.), Sproglige åbninger. Festskrift til Erik Hansen, 18. september 2001. København, s. 266-276.

Poulsen, Ib. (2006). Radiomontagen og dens rodder. Et studie $i$ den danske radiomontage med vagt på dens radiofoniske genreforudsatninger. København: Roskilde Universitetsforlag.

Schafer, R. Murray. (1977). The Tuning of the World. New York: Alfred A. Knopf.

Stevens, S. S. \& F. Warshofsky. (1965). Sound and Hearing. New York: Time-Life.

Theil, Per. (1999). "Radiofoniske fortællinger". In Jytte Wiingaard (red.), Medier og astetik. Medieteoriens historie og analysepraksis. København: Multivers, s. 47-102.

Truax, Barry. (2001). Acoustic Communication. Second Edition. Westport, Connecticut: Ablex Publishing.

Ib Poulsen er professor i dansk sprog og medievidenskab ved Roskilde Universitetscenter. 